\title{
Inter Seasonality of the Energy Fluxes in Brazilian Savana-Mato Grosso-Brazil
}

\author{
Leone Francisco Amorim Curado*, José de Souza Nogueira, Luciana Sanches, \\ Thiago Rangel Rodrigues, Francisco de Almeida Lobo, Marcelo Sacardi Bíudes \\ Federal University of Mato Grosso, Cuiabá, Brazil \\ Email: "leone@pgfa.ufmt.br, nogueira@ufmt.br, Isanches@hotmail.com, thiagorangel@pgfa.ufmt.br, \\ falobo@ufmt.br, marcelo@pgfa.ufmt.br
}

Received 13 February 2014; revised 10 March 2014; accepted 17 March 2014

Copyright (C) 2014 by authors and Scientific Research Publishing Inc.

This work is licensed under the Creative Commons Attribution International License (CC BY). http://creativecommons.org/licenses/by/4.0/

(c) (i) Open Access

\begin{abstract}
Dynamics of flows of matter and energy these biomes are relevant to understanding of environmental processes that govern the biosphere-atmosphere interactions and between ecosystems. This study analyzed inter season and season of energy fluxes in Brazilian Savana through Bowen Ration Method. Results show differences in patterns LE in all season, LE predominant in wet while $H$ in dry. This inversion in patterns of predominant components of the energy balance in wet and dry season because in wet season increase water content in soil and atmosphere due precipitation in this season providing more lost energy for atmosphere in shape LE through soil evaporation and plant transpiration, this results in LE and $H$ in all season of the Brazilian Savana show higher variation in dynamics energy fluxes between surface and atmosphere, as well as energy partition in this biome. Statistics analyses presents than many climate variables influences $L E$ and $H$ in each season indicating complexity in this fluxes. More study is necessary to higher understand patterns energies fluxes in Brazilian Savana.
\end{abstract}

\section{Keywords}

Patterns Energies; LE; H; Bowen Ration

\section{Introduction}

The state of Mato Grosso encompasses three of main biomes of South America-Amazon Rainforest, Cerrado and Pantanal, and the latter two have gained attention from researchers who study the phenomena that promote balance between human activities and nature because the dynamics of flows of matter and energy these biomes

"Corresponding author. 
are relevant to understanding of environmental processes that govern the biosphere-atmosphere interactions and between ecosystems.

The Cerrado is a corridor connecting the Pantanal to Caatinga, occupying the region between the two largest Neotropical rainforest: the Amazon rainforest and the Atlantic forest.

Neotropical savannas, and in particular the Cerrado, contain a mixture of many tree and herbaceous species having different responses to variations in environmental conditions. The climate is extremely seasonal with about five rainless months and a long period with high rainfall. Evaporative demand is substantially higher during the dry season when environmental conditions induce plant water stress in the shallow-rooted herbaceous species and for some relatively shallow-rooted woody species. In contrast, most trees have deep roots capable of tapping abundant and stable soil water resources [1].

Climate and vegetation strongly influence the water cycle on local to regional scales. A change in the surface energy and water balance, especially in dry climatic regions, can have a significant impact on local water availability [2], as well as in energy balance partition in the region.

According to the modelling approaches, ET can be estimated by multiplying crop coefficients by reference ET data from different kinds of models using measured microclimatological and underlying surface information. However, there are some limits in the modelling approaches. In addition, direct measurement methods, such as eddy covariance method and weighing lysimeter have not been widely used because of the high cost and difficulties of operation especially in wetlands [3] [4].

The quantification of LE and $\mathrm{H}$ by Bowen ratio method have been widely used in the last decade, for determining the energy balance in many studies about the energy dynamics of forest and management availability of water for certain crops by evapotranspiration estimated by the latent heat flux [5] [6].

The energy balance, based on the physical principle of energy conservation, lists the densities of energy flows available in the vegetation (net radiation) with the energy used, especially in the evaporation latent heat and sensible heat in variations air temperature and soil [7]. Micrometeorological methods quantify these flows and to assess the transformation of radiant energy into latent and sensible heat, thus representing the accounts of these interactions.

Latent and sensible heat are important parameters that directly drive variations in climate and can, in turn, alter the environmental variables driving the mass and energy exchange between the ground and the atmosphere [8]. Thus, latent and sensible heat fluxes are important variables in meteorological, hydrological and ecological analyses. By dividing energy flux components into latent and sensible heat, we can determine the water vapor and heat content of the atmosphere and better understand the regional and global scale climatological processes.

At present, the majority of our knowledge regarding wetland ecosystem energy balance is confined to the temperate, boreal, and arctic zones, with data principally collected only during the growing season. Little is known about energy exchange in wetlands of the subtropics and tropics where seasonality is best characterized by wet and dry seasons. The potential for year-round plant growth at low latitudes is likely to affect wetland energy balance differently during wet and dry periods of the year, as has been observed in some tropical terrestrial ecosystems [7] [9].

Energy, water, and carbon cycles in forest ecosystems are tightly coupled through the evapotranspiration (ET) processes [10]. Although land managers are more interested in water and carbon balances, quantifying forest energy balance offers insights to how management affects the forest microclimate and the feedbacks of land use change to climate change at a regional scale. Uncertainty about the combined consequences of afforestation or deforestation on regional climate and greenhouse gas emissions indicates the need for more research on the physical effects of forest management [11] [12].

Thus the purpose of this study was to evaluate the inter seasonality the latent and sensible heat flux and the relationship with the atmospheric variables in Brazilian Savana.

\section{Materials and Methods}

\subsection{Study Area}

The experimental site was located in Santo Antonio de Leverger, MT, Brazil, which is $15 \mathrm{~km}$ south of Cuiabá $\left(15^{\circ} 43^{\prime} \mathrm{S}: 56^{\circ} 04^{\prime} \mathrm{W}\right)$. The study site is within a grass-dominated cerrado that was degraded approximately 35 years ago after the partial clearing of cerrado woodland vegetation. According to Koppen, the climate of region is characterized as Aw, tropical semihumid, with dry winters and wet summers. Annual rainfall oscillates be- 
tween 800 and $1500 \mathrm{~mm}$ and annual temperature oscillates between $26.0^{\circ} \mathrm{C}$ and $27.5^{\circ} \mathrm{C}$, respectively, and rainfall is seasonal with a dry season extending from May to September [13]. The research area is on flat terrain at an elevation of $157 \mathrm{~m}$ above sea level. The regional soil type is a rocky, dystrophic red-yellow latosol locally known as a Solo Concrecionário Distrófico.

\subsection{Micrometeorological Measurements}

Termhygrometers and anemometers are installed at three heights, $5 \mathrm{~m}, 10 \mathrm{~m}$ and $18 \mathrm{~m}$ height above ground level. The balance radiometer, the piranômentro and photosynthetically active radiation sensor are installed to $5 \mathrm{~m}$ high. The plate heat flux is installed in the soil to $1.0 \mathrm{~cm}$ deep. Soil moisture is measured only $20 \mathrm{~cm}$ deep, due to the characteristic litólica of the soil.

\subsection{Calcules}

An alternative for obtaining data latent heat flux in this study was the energy balance equation. According Amiro [14], latente heat flux (LE) obtained like energy balance reside is a viable option when you have good data. Balance energy can be obtained through Equation (1).

$$
\begin{aligned}
& R_{n}=\mathrm{LE}+\mathrm{H}+G \\
& \mathrm{LE}=R_{n}-\mathrm{H}-G
\end{aligned}
$$

Where, $R_{n}$ is net radiation $\left(\mathrm{W} \cdot \mathrm{m}^{-2}\right)$, LE latente heat flux $\left(\mathrm{W} \cdot \mathrm{m}^{-2}\right), \mathrm{H}$ sensible heat flux $\left(\mathrm{W} \cdot \mathrm{m}^{-2}\right), G$ is a flux in soil $\left(\mathrm{W} \cdot \mathrm{m}^{-2}\right)$.

Sensible heat flux $(\mathrm{H})$ was calculated for Bowen ration method (Equation (3)), and errors of the estimated values were minimized using conditions proposed by Perez et al. (1999).

$$
\begin{gathered}
\mathrm{H}=\left(R_{n}-G\right) \frac{\beta}{(1+\beta)} \\
\beta=\gamma \frac{\Delta T}{\Delta e}
\end{gathered}
$$

where $\beta$ is Bowen ration, $\Delta T$ is temperature difference $\left({ }^{\circ} \mathrm{C}\right)$ between two height, $\Delta e$ is the vapor pressure difference $(\mathrm{kPa})$ and $\gamma$ is psychrometric constant $\left(\mathrm{kPa} \cdot{ }^{\circ} \mathrm{C}^{-1}\right)$.

The sky coverage can be expressed in terms of the index of atmospheric transmissivity (Nkemdirim, 1972), determined for day index $\left(K_{T}\right)$ (Equation (5)), calculated through ration between Global radiation $\left(R_{g}\right)$ and irradiation in atmosphere top $\left(R_{0}\right)$.

$$
\frac{R_{g}}{R_{0}}=K_{T}
$$

According Dallacort et al. [15], $0 \leq K_{T} \leq 0.3$ defined like cloudy, between $0.3 \leq K_{T} \leq 0.65$ partly cloudy and between $0.65 \leq K_{T} \leq 1$ clear sky.

\subsection{Statistic}

In this study was used mean with Mean Absolut Error (MAE) according recommended for Willmott and Matsuura [16]. To analyses seasons was used Bootstrap [17].

\section{Results and Discussion}

\subsection{Microclimate Variables in Wet and Dry Season}

In this study, wet and dry season were chosen according accumulated precipitation in the month. So to wet season were chosen months with accumulated precipitation higher to $50 \mathrm{~mm}$ and below this values was considered dry season. Figure 1 presents precipitation between may/2009 and February/2012.

Months of wet season in site were January, February, March, April, October, November and December, while other months characterized dry season. 


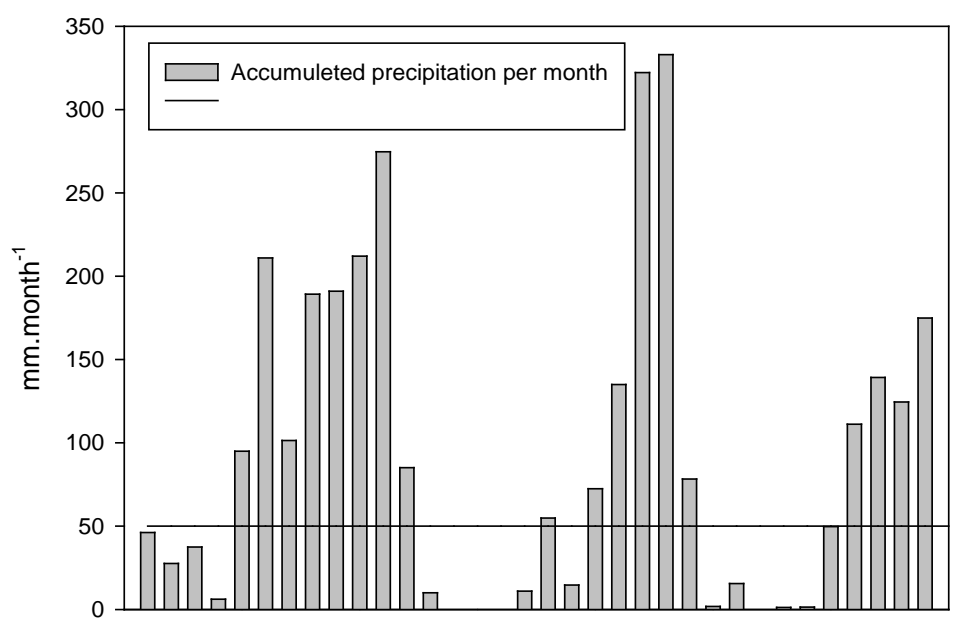

may/2009 may/2010 may/2011 feb/2012

Figure 1. Accumuleted precipitation per month between May/2009 and February/ 2012 in Brazilian Savana.

In wet seasons, average value temperature $\left({ }^{\circ} \mathrm{C}\right.$ ) was $27.75 \pm 1.77$ between $10 / 2009$ and $04 / 2010,28.11 \pm 1.71$ between $10 / 2010$ and $04 / 2011$ and $28.58 \pm 1.50$ between $10 / 2011$ and $02 / 2012$. While in dry season this values were $26.40 \pm 3.18$ in 2009, $27.24 \pm 3.99$ in 2010 and $27.83 \pm 3.80$ in 2011. Figure 2 presents temperature daily average values in wet and dry seasons.

Temperature have been higher variation patters in dry season due air moisture was lower this season while wet season. Thus, water is better conductor than dry air, so due higher air moisture in wet season caused lower variation patter in temperature air values, it indicate than water is a thermic regulator in air temperature. About values temperature was higher in wet season which dry season, its due wet season in site was in spring and summer, two seasons which sun is in south, thus the higher global radiation in site was in this season, and higher global radiation caused higher temperature values. Chen et al. [5] studding energy balance in northern hemisphere found also higher temperature values in July (summer in this hemisphere).

Thus, two factors characterized local temperature: first-higher patters variation in dry season and higher values in wet season. Theses factor were determined for two different causes: first-air moisture controls the variation patterns in air temperature and sun localization (due year season) controls global radiation in surface.

Global radiation and net radiation values in wet season were respectively, in $\mathrm{W} \cdot \mathrm{m}^{-2}, 202.82 \pm 45.37$ and $177.39 \pm$ 45.37, $203.83 \pm 45.08$ and $216.29 \pm 69.13,216.03 \pm 42.40$ and $274.30 \pm 61.43$ between 2009/2010, 2010/2011, 2011/2012. In dry seasons these values were $179.34 \pm 40.19$ and $209.16 \pm 47.32,188.15 \pm 27.68$ and $183.03 \pm$ 41.97, $195.07 \pm 34.21$ and $179.79 \pm 73.55$ in 2009, 2010 and 2011 respectively. Figure 3 and Figure 4 present global and net radiation values in wet and dry season between 2009 and 2012.

In general global radiation values were higher in wet season due sun localization (spring and summer in southern Hemisphere) and net radiation patterns are like global radiation due this variable influences directly net radiation.

\subsection{Seasonal and Inter-Seasonal Variation in LE and $\mathrm{H}$}

According to Table 1, higher variation in LE was in wet seasons in 2009/2010 and 2010/2011, while H values were against LE values. Schedlbauer et al. [18], in Everglades Florida study found similar patterns in LE and H this local. The author also relate despite environmental extremes, fluxes of $\mathrm{H}$ and LE from this short-hydroperiod marsh are relatively predictable and highly related to variation in $\mathrm{Rn}$, provided that the site's hydroperiod mirrors south Florida's climatic seasonality. Other environmental factors influencing $\mathrm{H}$ and LE vary seasonally and are at least partly under human control. Higher water content in atmosphere and in soil, and larger global radiation in this season contribute for soil evaporation and plant transpiration causing great latent heat flux in site.

Relationship between $L E / R_{n}$ and $\mathrm{H} / R_{n}$ were respectively, 0.48 and $0.42,0.48$ and $0.45,0.42$ and 0.41 in wet seasons; 0.20 and 0.59, 0.08 and 0.90, 0.53 and 0.59 in dry seasons. Note when LE values decreases, increases $\mathrm{H}$ 


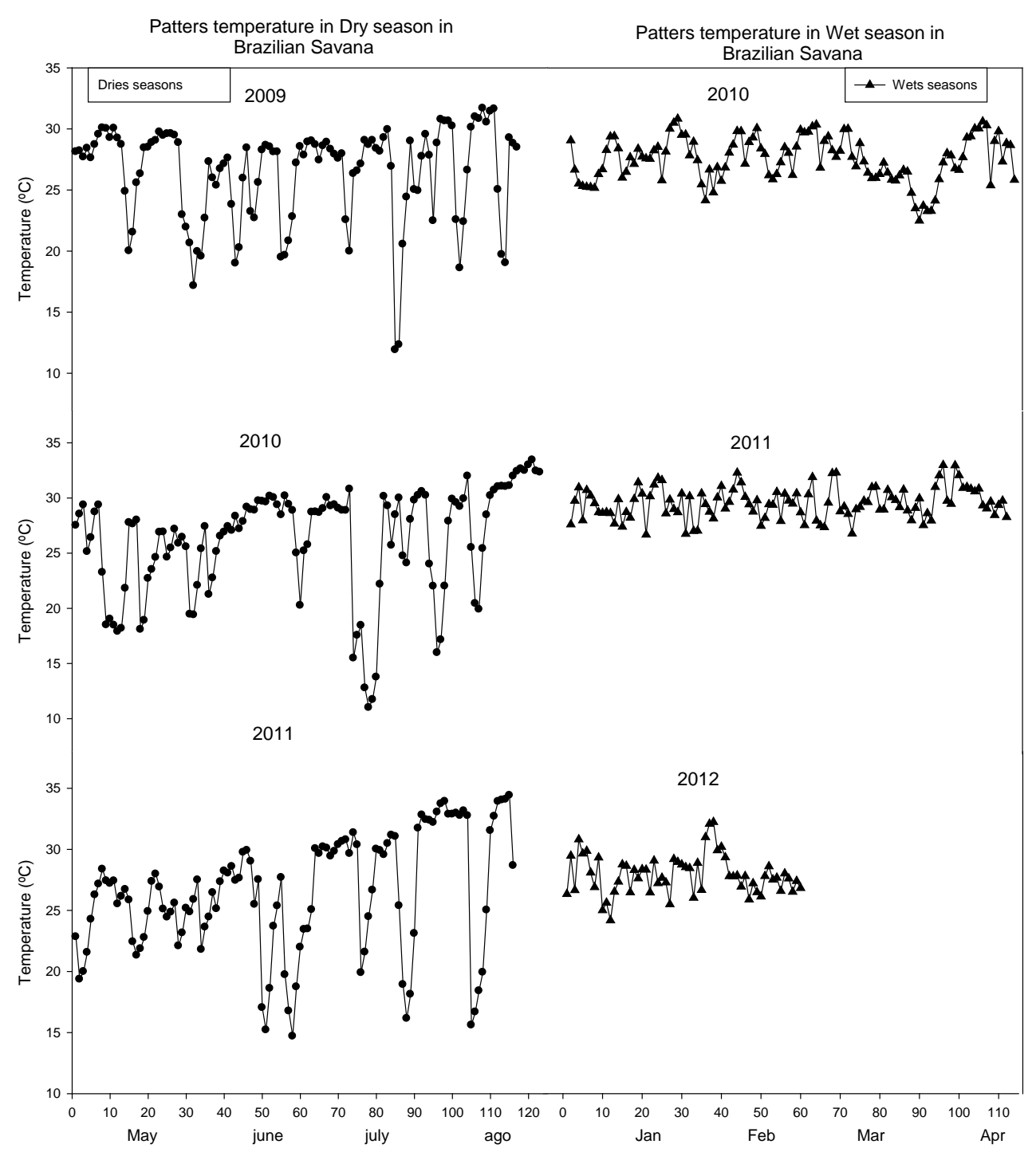

Figure 2. Daily average values of temperature in wet and dry season during 2009 and 2012 in Brazilian Savana.

Table 1. Higher, lower and average values of latent and sensible heat fluxes in wet and dry season between 2009 and 2012 in Brazilian Savanas.

\begin{tabular}{cccccccc}
\hline & & \multicolumn{3}{c}{ Wet seasons } & \multicolumn{3}{c}{ Dry seasons } \\
\hline & & $\mathbf{2 0 1 0}$ & $\mathbf{2 0 1 1}$ & $\mathbf{2 0 1 2}$ & $\mathbf{2 0 0 9}$ & $\mathbf{2 0 1 0}$ & $\mathbf{2 0 1 1}$ \\
\hline $\mathbf{L E}$ & Higher & 331.55 & 339.29 & & 126.57 & 134.97 & 261.00 \\
$\left(\mathbf{W} \cdot \mathbf{m}^{-\mathbf{2}}\right)$ & Lower & 17.71 & 0.81 & 5.79 & 1.61 & 0.62 \\
& Average & $163.67 \pm 54.98$ & $174.28 \pm 50.84$ & & $56.7 \pm 23.54$ & $36.73 \pm 22.53$ & $72.10 \pm 44.40$ \\
& Higher & 235.46 & 264.08 & 212.06 & 255.74 & 262.38 \\
$\mathbf{H}$ & Lower & 11.79 & 14.54 & & 22.27 & 6.37 & 1.12 \\
$\left(\mathbf{W} \cdot \mathbf{m}^{-\mathbf{2}}\right)$ & Average & $133.22 \pm 32.62$ & $144.84 \pm 39.37$ & & $132.50 \pm 33.58$ & $131.18 \pm 54.82$ & $61.85 \pm 52.32$ \\
\hline
\end{tabular}

values and higher values LE were in wet seasons while $H$ were in dry season, similar patterns found in Chen et al. [5] in Asia study. Giambeluca et al. [6] in two different Savana study found LE/ $R_{n}$ and H/R $R_{n}$ values respectively 0.52 and $0.28,0.44$ and 0.31 in wet season, 0.42 and $0.37,0.3$ and 0.55 in dry season. Thus, there are different spatial values in energy partition in Savana due vegetation type in local. 


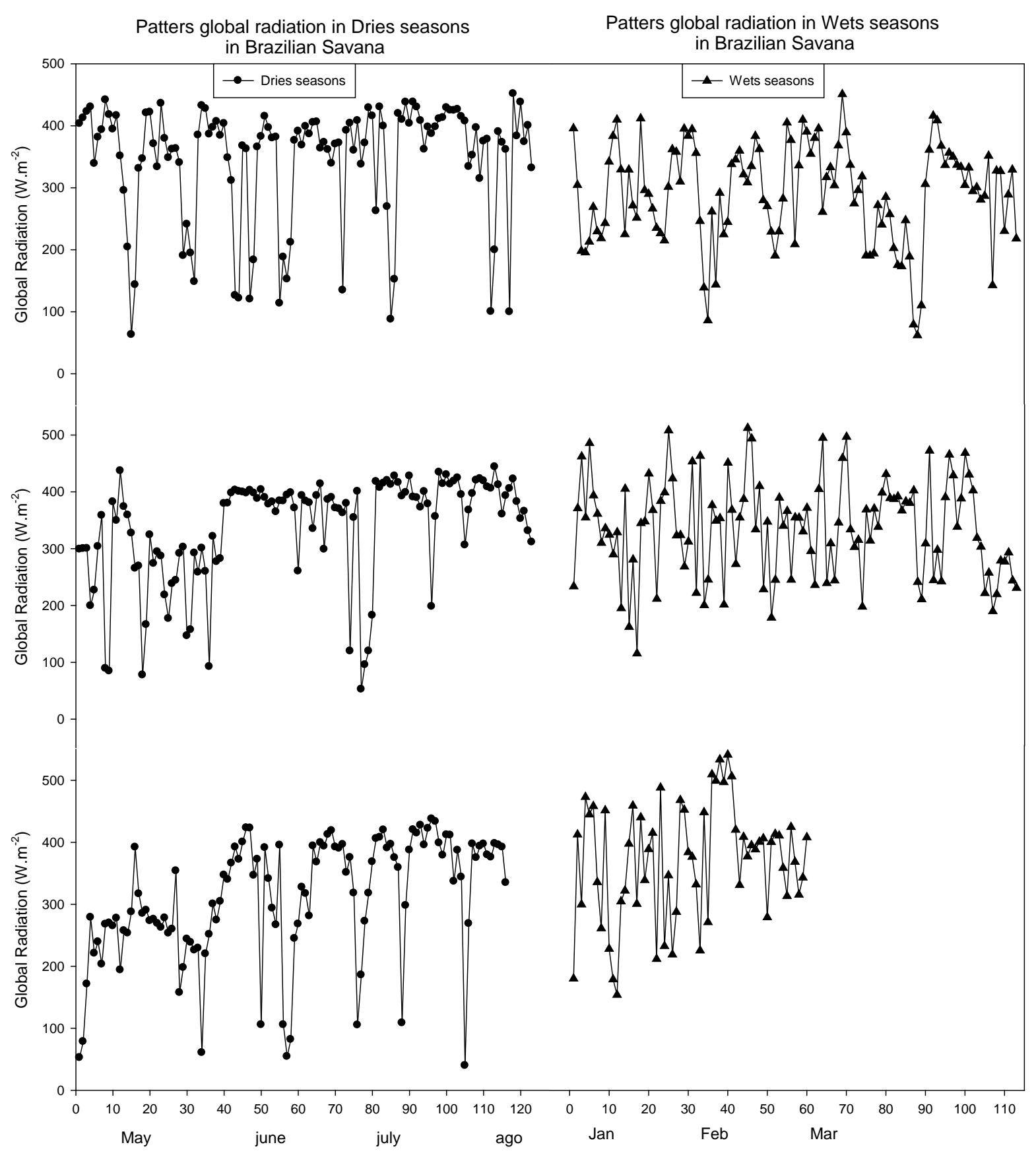

Figure 3. Daily average values of global radiation in wet and dry season during 2009 and 2012 in Brazilian Savana.

In all season sum of LE and $\mathrm{H}$ was above $80 \%$ of energy balance indicating that great contributes for energy balance closure were because these two variables. Schedlbauer et al. [18] in wetlands study found values sum of $\mathrm{LE}$ and $\mathrm{H}$ above $70 \%$, indicating also this biome the patterns in energy balance closure is similar Brazilian Savana.

LE values is many important to understand energy change fluxes between atmosphere and surface because Throughout much of the tropics, LE fluxes strongly dominate energy losses from terrestrial ecosystems yearround [9] [13]. Figure 4 and Figure 5 present LE Bootstrap and LE an H in wet and dry seasons, respectively.

According to Figure 5, note LE predominant in wet season, while in dry season H predominates over LE. This is a justification about inversion in patterns of predominant components of the energy balance in wet and dry season 


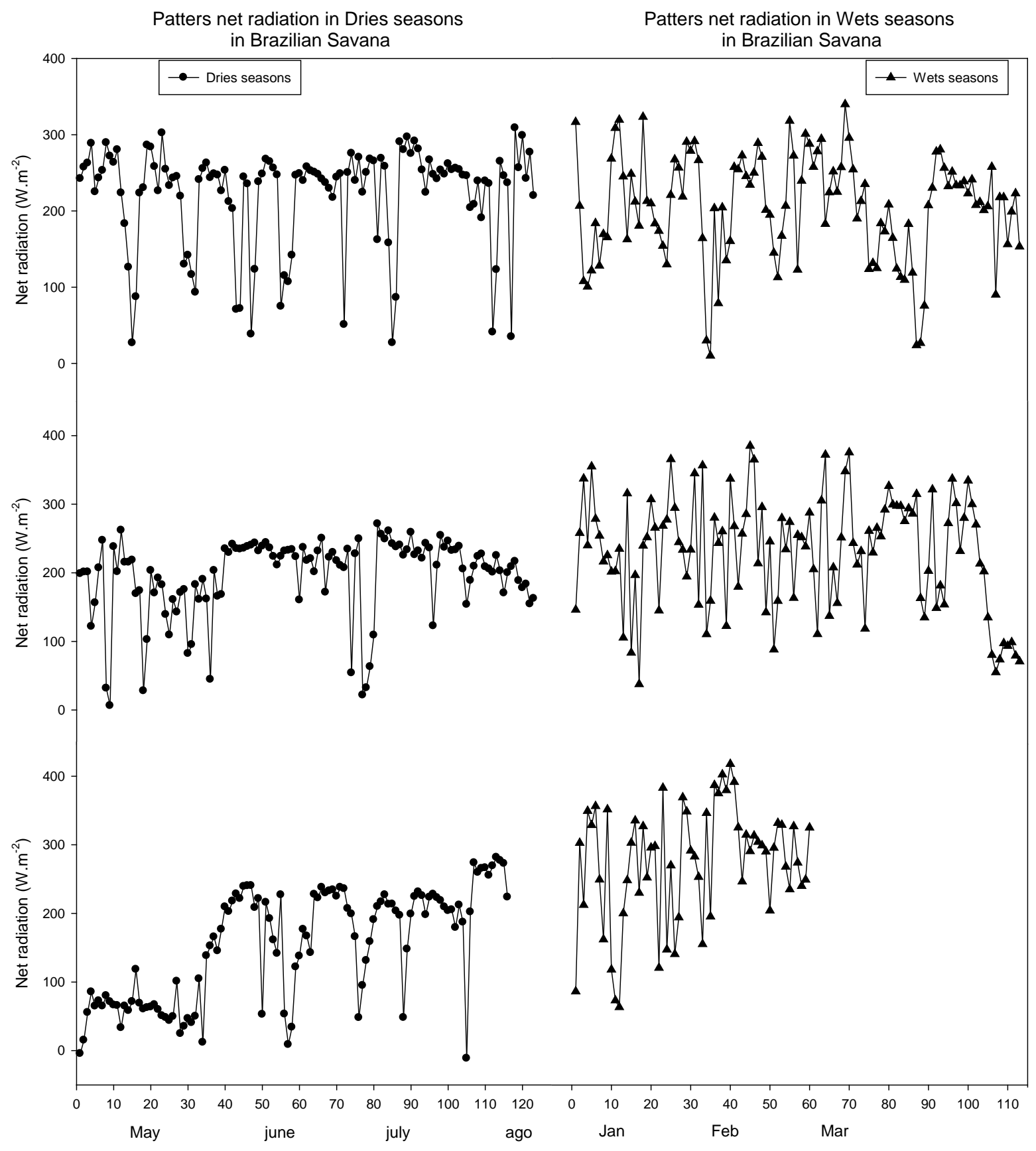

Figure 4. Daily average values of net radiation in wet and dry season during 2009 and 2012 in Brazilian Savana.

because in wet season increase water content in soil and atmosphere due precipitation in this season providing more lost energy for atmosphere in shape LE through soil evaporation and plant transpiration. Sun et al. [19] in study in loblolly pine plantations in North Carolina, USA and Lenters et al. [2] in study about wetlands in Nebraska, USA found similar patterns in increase $\mathrm{H}$ and decrease LE in dry season.

This results in LE and $\mathrm{H}$ in all season of the Brazilian Savana show higher variation in dynamics energy fluxes between surface and atmosphere, as well as energy partition in this biome.

According to Bootstrap analyses (Figure 6 and Figure 7) note LE were different in all seasons. These results indicate rainfall was determinant factor in season and inter-season in site, great precipitation in wet season and very lower precipitation in dry season caused different patterns in energy partition with inversion between LE and H 


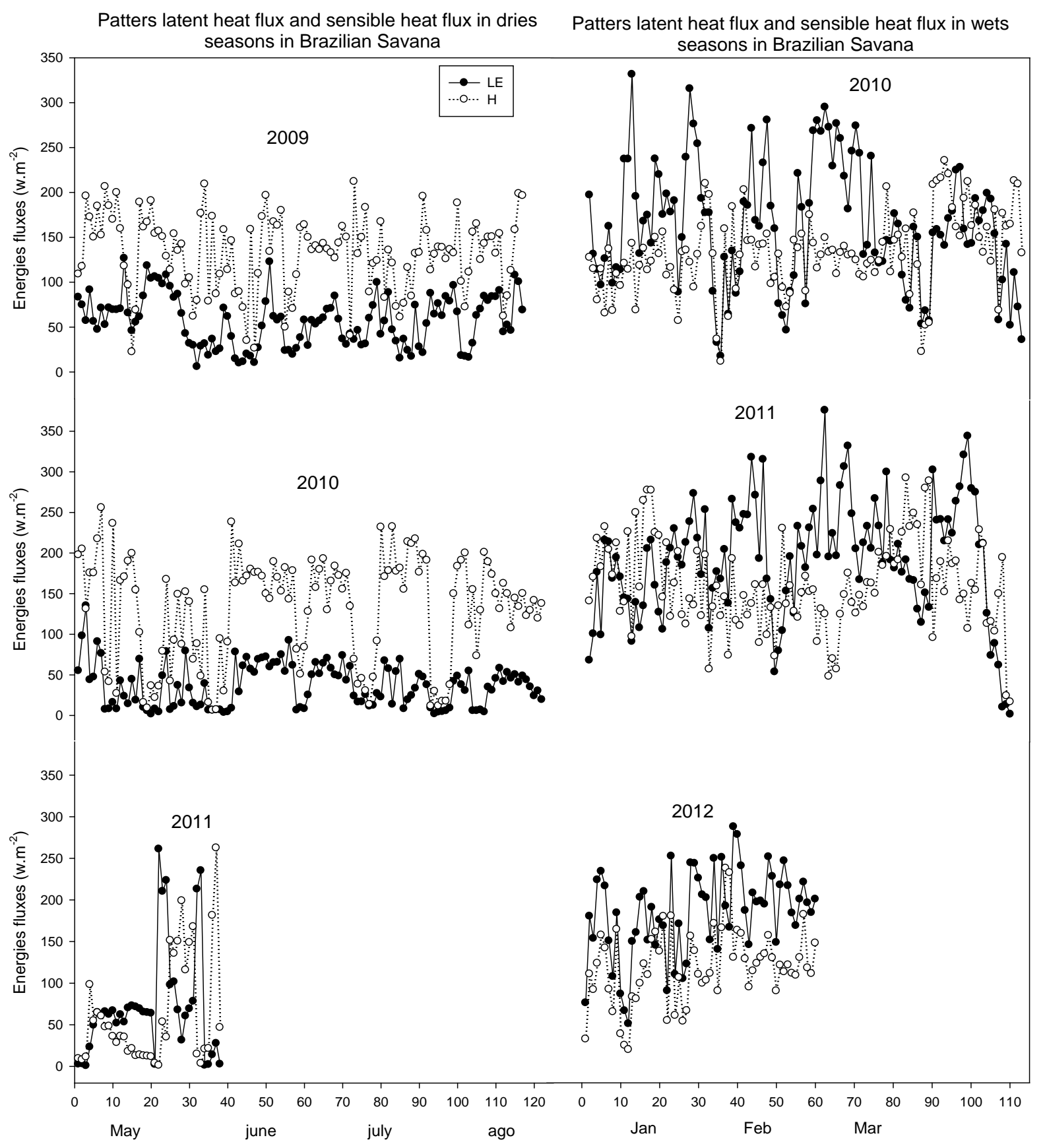

Figure 5. Daily average values of LE and H in wet and dry season during 2009 and 2012 in Brazilian Savana.

in two seasons. Higher water content in soil and atmosphere due precipitation resulted in higher LE in energy partition in wet season. About inter-seasons, differences in LE in same season in three progressive years were due differences in accumulated precipitation in each wet season (see Figure 8), different patterns in precipitation caused differences in energy partition in annual seasons.

\subsection{Climatic Controls of Latent and Sensible Heat Fluxes}

Analyses of climatic controls of LE and $\mathrm{H}$ were done through Pearson correlation ( $\mathrm{p}<0.05)$ between LE, H and some climatic variables. Correlation results show variables controls LE and $\mathrm{H}$ changed in different seasons and also the same season in different years. Table 2 presents these correlations. 


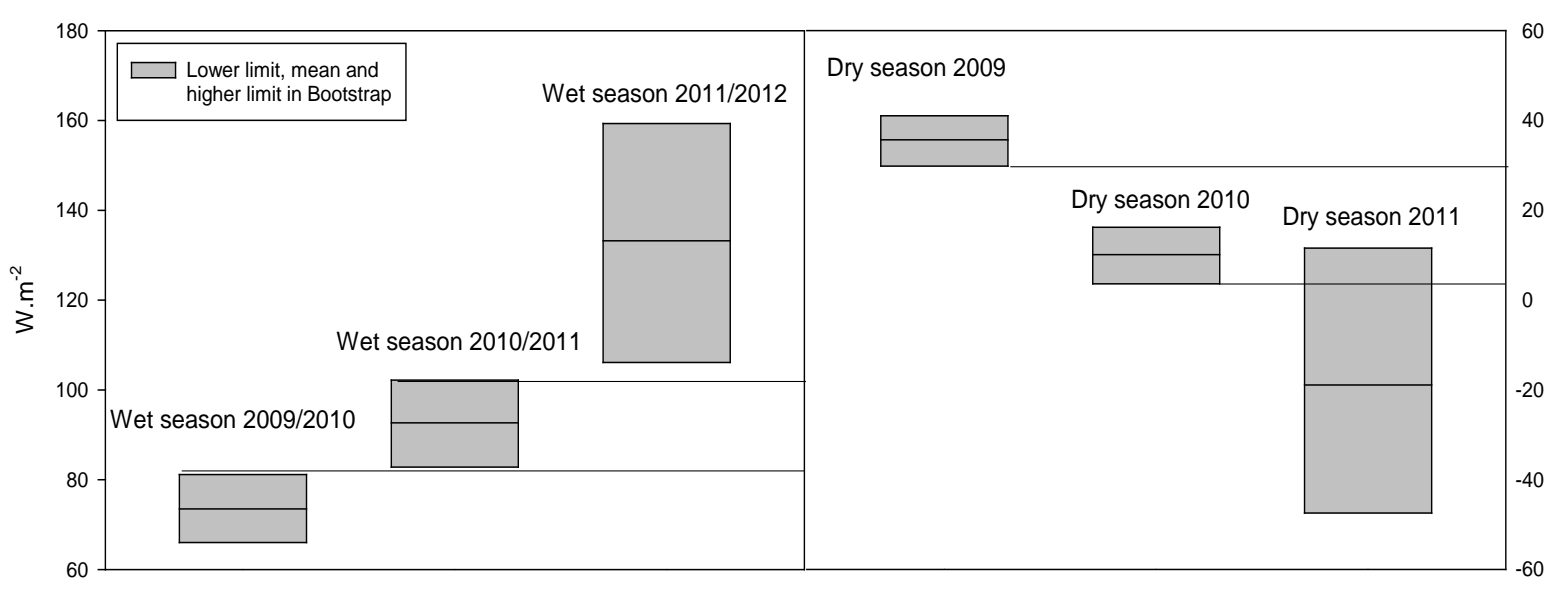

Figure 6. LE Bootstrap in wet and dry season between 2009 and 2012.

H -Bootstrap - Wet seasons

H - Bootstrap - Dries seasons

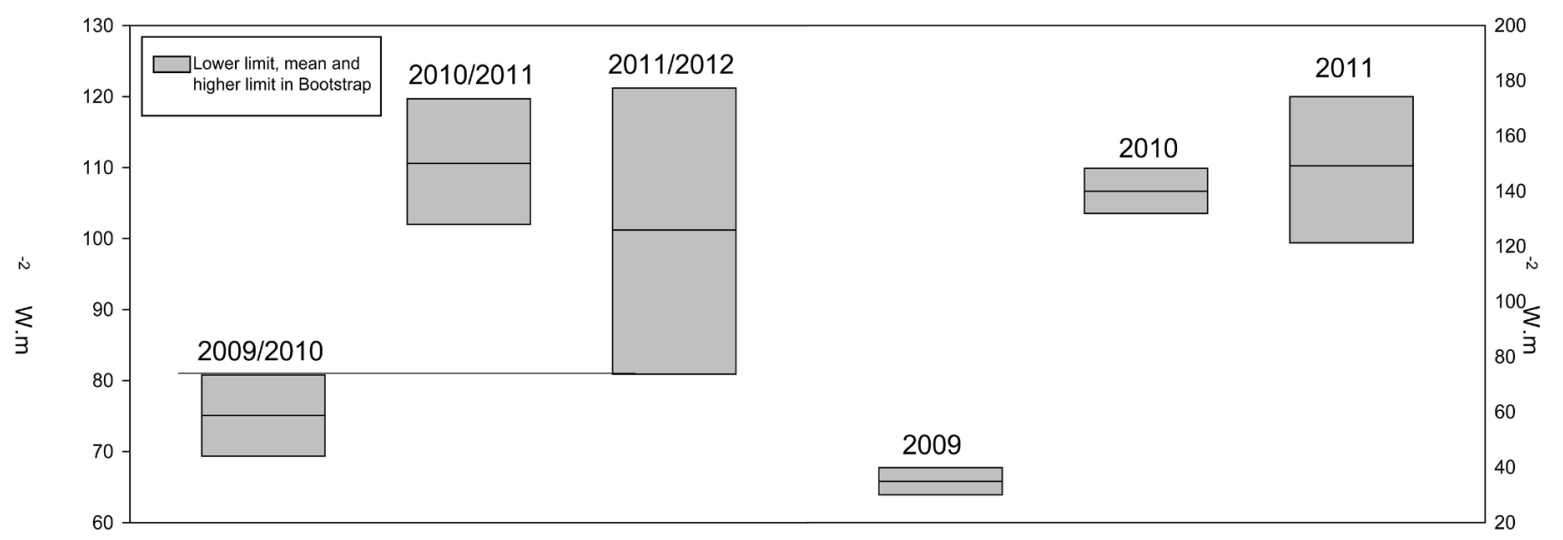

Figure 7. H Bootstrap in wet and dry season between 2009 and 2012.

Table 2. Pearson correlation ( $\mathrm{p}$ <.05) between latent heat flux (LE), sensible heat flux $(\mathrm{H})$, net radiation $\left(R_{n}\right)$ temperature (T), relative humidity $(\mathrm{RH})$, vapor deficit pressure (VDP), solar radiation $\left(R_{q}\right)$, and sky coverage $\left(K_{T}\right)$ for the wets seasons 2009-2012 in Brazilian Savana.

\begin{tabular}{|c|c|c|c|c|c|c|c|c|c|c|c|c|}
\hline & \multicolumn{6}{|c|}{ DRIES SEASONS } & \multicolumn{6}{|c|}{ WETS SEASONS } \\
\hline & \multicolumn{2}{|c|}{2009} & \multicolumn{2}{|c|}{2010} & \multicolumn{2}{|c|}{2011} & \multicolumn{2}{|c|}{2010} & \multicolumn{2}{|c|}{2011} & \multicolumn{2}{|c|}{2012} \\
\hline & LE & $\mathbf{H}$ & $\mathbf{L E}$ & $\mathbf{H}$ & LE & $\mathbf{H}$ & $\mathbf{L E}$ & $\mathbf{H}$ & LE & $\mathbf{H}$ & LE & $\mathbf{H}$ \\
\hline LE & 1 & & 1 & & 1 & & 1 & & 1 & & 1 & \\
\hline $\mathbf{H}$ & 0.68 & 1 & 0.76 & 1 & 0.91 & 1 & 0.42 & 1 & 0.43 & 1 & 0.68 & 1 \\
\hline $\boldsymbol{R}_{n}$ & 0.52 & 0.64 & 0.47 & 0.68 & 0.38 & 0.54 & 0.89 & 0.74 & 0.75 & 0.58 & 0.64 & 0.73 \\
\hline $\mathbf{T}$ & 0.5 & 0.19 & 0.64 & 0.49 & 0.44 & 0.2 & 0.74 & 0.44 & 0.48 & 0.55 & 0.5 & 0.19 \\
\hline UR & -0.4 & -0.3 & 0.45 & 0.35 & 0.42 & 0.29 & 0.77 & 0.55 & 0.83 & 0.54 & 0.29 & 0.32 \\
\hline DPV & 0.4 & 0.19 & 0.69 & 0.5 & 0.45 & 0.22 & 0.8 & 0.45 & 0.37 & 0.81 & 0.4 & 0.19 \\
\hline $\boldsymbol{R}_{g}$ & 0.55 & 0.63 & 0.56 & 0.63 & 0.21 & 0.36 & 0.87 & 0.74 & 0.5 & 0.79 & 0.63 & 0.66 \\
\hline$K_{T}$ & 0.69 & 0.33 & 0.67 & 0.65 & 0.16 & 0.38 & 0.78 & 0.77 & 0.74 & 0.53 & 0.65 & 0.69 \\
\hline
\end{tabular}




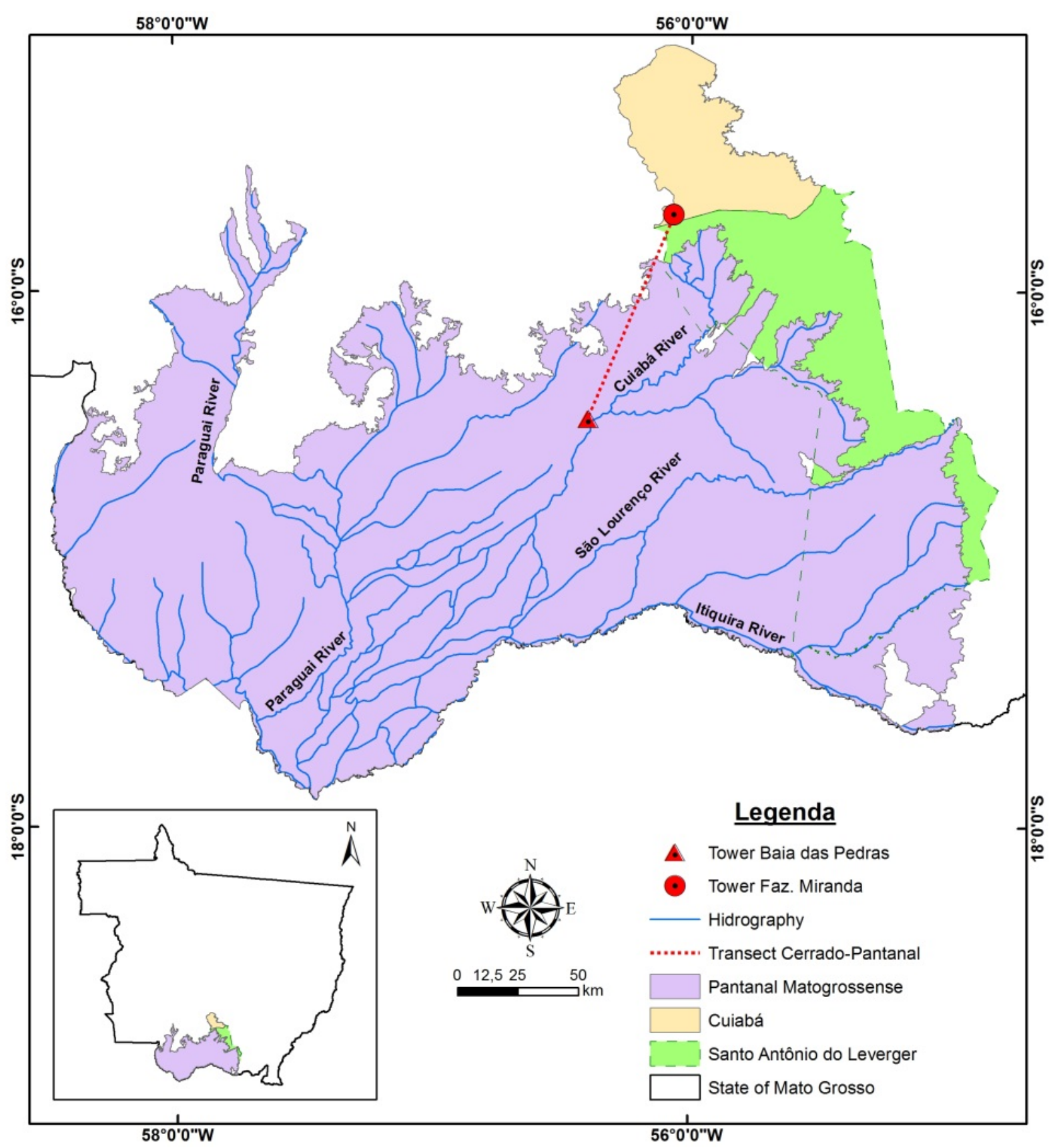

Figure 8. Micrometeorological tower localization of Brazilian Savana and Pantanal.

Correlation values show complexity in relation between LE, H and climatic variables. LE and $\mathrm{H}$ are well correlated with $R_{n}$ and $R_{g}$ in all seasons, other variables correlate with energy fluxes like air temperature, soil moisture in wet season and Pressure Vapor Deficit, air temperature, day index in dry season. This results show some atmospheric variables influences LE and $\mathrm{H}$ in wet and dry season indicating higher complexity in these variables.

\section{Conclusions}

In general global radiation values were higher in wet season due sun localization (spring and summer in southern Hemisphere) and net radiation patterns are like global radiation due this variable influences directly net radi- 
ation

In all season sum of LE and $\mathrm{H}$ was above $80 \%$ of energy balance indicating that great contributes for energy balance closure were because these two variables. LE predominant in wet season due higher water content in atmosphere, but in dry season there was inversion being $H$ higher in energy balance.

According Bootstrap analyses LE were different in all seasons indicating rainfall was determinant factor in season and inter-season in site, great precipitation in wet season and very lower precipitation in dry season caused different patterns in energy partition with inversion between LE and $H$ in two season.

Many climates variables influence LE and $\mathrm{H}$ in seasons, being $R_{n}$ and $R_{g}$ in all season and other variables in wet or dry season indicating higher complexity in LE and $\mathrm{H}$ patterns.

\section{Acknowledgements}

The authors thank Coordenação de Aperfeiçoamento de Pessoal do Ensino Superior (CAPES), Conselho Nacional de Desenvolvimento Científico e Tecnológico (CNPq) for Scholarship and Fundo de Amparo a Pesquisa do Estado de Mato Grosso (FAPEMAT) through the Support Program for Centers of Excellence (PRONEX) for financial support to the research project process no. 823971/2009 and Prof. Clovis Nobre Miranda PPGFA by collaboration with the space allowed for installation of micrometeorological tower on his property.

\section{References}

[1] Scholz, F.G., Bucci, S.J., Goldstein, G., Moreira, M.Z., Meinzer, F.C., Domec, J.-C., Villalobos Vega, R., Franco, A.C. and Miralles-Wilhelm, F. (2008) Biophysical and Life History Determinants of Hydraulic Lift in Neotropical Savanna Trees. Functional Ecology, 22, 773-786. http://dx.doi.org/10.1111/j.1365-2435.2008.01452.x

[2] Lenters, J.D., Cutrell, G.J., Istanbulluoglu, E., Scott, D.T., Herrman, K.S., Irmak, A. and Eisenhauer, D.E. (2011)Seasonal Energy and Water Balance of a Phragmites Australis-Dominated Wetland in the Republican River Basin of South-Central Nebraska (USA). Journal of Hydrology, 408, 19-34. http://dx.doi.org/10.1016/j.jhydrol.2011.07.010

[3] Valiantzas, J.D. (2006) Simplified Versions for the Penman Evaporation Equation Using Routine Weather Data. Journal of Hydrology, 331, 690-702. http://dx.doi.org/10.1016/j.jhydrol.2006.06.012

[4] Zhou, L. and Zhou, G.S. (2009) Measurement and Modelling of Evapotranspiration over a Reed (Phragmites australis) Marsh in Northeast China. Journal of Hydrology, 372, 41-47. http://dx.doi.org/10.1016/j.jhydrol.2009.03.033

[5] Chen, S., Chen, J., Lin, G., Zhang, W., Miao, H., Wei, L., Huang, J. and Han, X. (2009) Energy Balance and Partition in Inner Mongolia Steppe Ecosystems with Different Land Use Types. Agricultural and Forest Meteorology, 149, 1800-1809.

[6] Giambelluca, T.W., Scholz, F.G., Bucci, S.J., Meinzer, F.C., Goldstein, G., Hoffmann, W.A., Franco, A.C. and Buchert, M.P. (2009) Evapotranspiration and Energy Balance of Brazilians Savannas with Contrasting Tree Density. Agricultural and Forest Meteorology, 149, 1365-1376. http://dx.doi.org/10.1016/j.jhydrol.2009.03.033

[7] Malhi, Y., Pegoraro, E., Nobre, A.D., Pereira, M.G.P., Grace, J., Culf, A.D. and Clement, R. (2002) The Energy and Water Dynamics of a Central Amazonian Rain Forest. Journal of Geophysical Research, 107, LBA 45-1-LBA45-17.

[8] Falge, E., Reth, S., Brüggemann, N., Butterbach-Bahl, K., Goldberg, V., Oltchev, A., Schaaf, S., Spindler, G., Stiller, B., Queck, R., Köstner, B. and Bernhofer, C. (2005) Comparison of Surface Energy Exchange Models with Eddy Flux Data in Forest and Grassland Ecosystems of Germany. Ecological Modelling, 188, 174-216. http://dx.doi.org/10.1016/j.ecolmodel.2005.01.057

[9] Von Randow, C., Manzi, A.O., Kruijt, B., De Oliveira, P.J., Zanchi, F.B., Silva, R.L., Hodnett, M.G., Gash, J.H.C., Elbers, J.A., Waterloo, M.J., Cardoso, F.L. and Kabat, P. (2004) Comparative Measurements and Seasonal Variations in Energy and Carbon Exchange over Forest and Pasture in South West Amazonia. Theoretical and Applied Climatology, 78, 5-26.

[10] Noormets, A., Ewers, B., Sun, G., Mackay, S., Zheng, D., McNulty, S.G. and Chen, J. (2006) Water and Carbon Cycles in Heterogeneous Landscapes: An Ecosystem Perspective. In: Chen, J., Saunders, S.C., Brosofske, K.D. and Crow, T.R., Eds., Linking Ecology to Landscape Hierarchies, Nova Publishing, Carbondale, 89-123.

[11] Bala, G., Caldeira, K., Wickett, M., Phillips, T.J., Lobell, D.B., Delire, C. and Mirin, A. (2007) Combined Climate and Carbon-Cycle Effects of Large-Scale Deforestation. Proceedings of the National Academic Sciences United States America, 104, 6550-6555. http://dx.doi.org/10.1073/pnas.0608998104

[12] Juang, J.-Y., Katul, G.G., Siqueira, M.B.S., Stoy, P.C. and Novick, K.A. (2007) Separating the Effects of Albedo from Eco-Physiological Changes on Surface Temperature along a Successional Chronosequence in the Southeastern US. 
Geophysical Research Letters, 34, Article ID: L21408. http://dx.doi.org/10.1029/2007GL031296

[13] Vourlitis, G.L., Nogueira, J.D.S., Lobo, F.D.A., Sendall, K.M., de Paulo, S.R., Dias, C.A.A., Pinto, O.B.P. and de Andrade, N.L.R. (2008) Energy Balance and Canopy Conductance of a Tropical Semi-Deciduous Forest of the Southern Amazon Basin. Water Resources Research, 44, Article ID: W03412. http://dx.doi.org/10.1029/2007GL031296

[14] Amiro, B. (2009) Measuring Boreal Forest Evapotranspiration Using the Energy Balance Residual. Journal of Hidrology, 366, 112-118.

[15] Dallacort, R., Ricieri, R.P., Silva, S.L., Freitas, P.S.L. and Silva, F.F. (2004) Análise do comportamento de um actinógrafo bimetálico (R. Fuess-Berlin-Steglitz) em diferentes tipos de cobertura do céu. Acta Scientiarum Agronomy, 26, 413-419.

[16] Willmott, C.J. and Matsuura, E.K. (2005) Advantages of the Mean Absolute Error (MAE) over the Root Mean Square Error (RMSE) in Assessing Average Model Performance. Climate Research, 30, 79-82. http://dx.doi.org/10.3354/cr030079

[17] Sokal, R.R., Rohlf, F.J. (1998) Biometry: The Principles and Practice of Statistics in Biological Research. W. H. Freeman, New York, 887 p.

[18] Schedlbauer, J.L., Oberbauer, S.F., Starr, G. and Jimenez, K.L. (2011) Controls on Sensible Heat and Latent Energy Fluxes from a Short-Hydroperiod Florida Everglades Marsh. Journal of Hydrology, 411, 331-341.

[19] Sun, G., Noormets, A., Gavazzi, M.J., McNulty, S.G., Chen, J., Domec, J.C., King, J.S., Amatya, D.M. and Skaggs, R.W. (2010) Energy and Water Balance of Two Contrasting Loblolly Pine Plantations on the Lower Coastal Plain of North Carolina, USA. Forest Ecology and Management, 259, 1299-1310.

http://dx.doi.org/10.1016/j.foreco.2009.09.016 